\title{
Marketing Analysis Strategy Organic Rice At Ud. Padi Marketing Region Bekasi With Single Agent (Yasin Holistic Super Organic)
}

\author{
Euis Dasipah ${ }^{1 *}$, Is Zunaini Nursinah², Taryadi ${ }^{3}$ \\ 1 UIN Sunan Gunung Djati Bandung \\ 2Postgraduate of Sunan Gunung Djati Bandung \\ ${ }^{3}$ Postgraduate of Sunan Gunung Djati Bandung \\ *Corresponding Author, E-Mail: euis.dasipah@yahoo.com
}

\begin{abstract}
Organic food (organic rice) actually is not something new for Indonesian people. Before "Green Revolution" (1960th), Indonesian farmers have produced rice without using chemical pest and fertilizer (conventional rice). Holistic Super Organic (HSO) rice is one of the brand organic rice, which is sold in Indonesia's market. Usaha Dagang (U.D. Padi) is the company, which is special to produce, and marketing HSO rice. The research is wanted to know marketing strategy HSO rice, especially in district of Bekasi with SWOT analysis. This research used case study methods with held by interview and literature study. The result of analyzing identified that the strengths from U.D. Padi was dominant and the opportunities so on. So, the next plan of marketing's strategy for is Aggressive Strategy. Aggressive Strategy is the effort to maximalize the strengths to get the opportunities optimally. The strengths of U.D. Padi is the especially of product and the distribution strategy which was held with excellent. The opportunities U.D. Padi is the wealth people who was increasing and the distributor channel who was welcome.
\end{abstract}

Keywords: Organic Rice, Holistic Super Organic (HSO).

\section{A. INTRODUCTION}

Since the time of the "Green Revolution" in the early 1960s, efforts to increase rice product1on prioritize economic incentives and tend to ignore other problems. Efforts to increase rice production have been carried out using chemical fertilizers and pesticides that were not controlled. The use of chemical fertilizers and pesticides in rice plants were initially favorable starting inefficient. Over the last 20 years, an increase of chemical fertilizer requirements by $500 \%$, while rice production increased by only $50 \%$ (Adiningsih, 2005).

Currently, based on the research results, the effort had a negative impact not only on the environment but also to human health. According to data from the World Health Organization (WHO), every year in developing countries, including Indonesia, there were 75,000 people and 14,000 suffering from insecticide poisoning fatalities (Andoko, 2005). The negative impact of the use of chemical fertilizers and pesticides raises awareness for some people to re-consuming chemical-free rice or often referred to as organic rice. Organic rice is one commodity that has a chance to develop; it is because organic rice has several advantages not possessed by unusual or non-organic rice. Bustanul in Portalhr (2008), stated that the organic rice market in Indonesia worth 28 billion dollars with a growth of 22 percent per year. Although prospective, it does not mean organic rice business growing without constraints and barriers. The main obstacle for the sale of organic rice is about marketing and high prices. 
According to Andoko (2005), states that the marketing of organic rice in Indonesia is different from regular rice. Organic rice only sold in the form of grain. Marketing process is usually done growers to rice traders in the market or entrusted to the supermarket or some are sold directly to consumers. When the rice is sold to traders in the market, the farmers have their income but it was not optimal because the traders took the profit as well. Meanwhile, when a farmer sells or entrust to the supermarket, the farmer gets a higher profit but the payment is not in cash but after rice is sold (on consignment). The farmers are able to sell directly to consumers anytime.

Currently, organic rice in the market is made up of 2 types, namely semi-organic rice and organic grains. Rice semi-organic is organic rice cultivated with organic farming systems, but grown on land tl1at has been contaminated with chemical fertilizers and pesticides, while organic grains of rice are cultivated lvithorganic farming systems and planted in a new or used intensive land that has been carried out sterilization of land. Examples of pure organic rice is rice Holistic Super Organic (rice HSO) produced by Usaha Dagang Padi (U.D. Padi), is one of many companies that produce organic rice market in Indonesia, has a network of distributors and agents spread across the region in Indonesia. One of the areas of marketing U.D. Padi is Bekasi area (city and regency).

Based on sales data, particularly in me area of Bekasi, has increased very significantly, driven by various factors both internal and external to U.D. Padi, especially the Single Agent "Yasin HSO". Therefore, it becomes interesting to learn about rice marketing HSO, especially in the area of Bekasi.

\section{B. METHODOLOGY}

This research used case study methods with held by interview and literature study by examining a variety of journals and books related to marketing strategy. Therefore, the method used in this study is analytic, in that this study will analyze the logic of ideas proposed by the figure under discussion and to elucidate the meaning of his concepts. Also, the method used in this study is a survey research, using the approach verificative explanatory research and causality testing. Purpose of explanatory research is to know and explain "why" something happened, whereas causality verification testing is research that explains the causal relationship between the study variables through testing hypothesis.

\section{RESULTS AND DISCUSSION}

Environmental Analysis of Organic Rice Marketing at U.D Padi, Bekasi Marketing Region, Single Agent "Yasin HSO". Analysis of the corporate environment is all factors that are affecting companies around the company achievement. It is faced with the internal environment and the external environment.

\section{Internal Environment Company}

One of the most important in the company is marketing management: analysis of the planning, execution, and control of programs designed to create, establish, and maintain beneficial exchanges with target buyers in order to achieve organizational goals (Sumarni, 2008). This section is in charge of preparing a strategy for the product to be seen, accepted and enjoyed or consumed by the public. 


\section{a. Product Strategy}

Rice HSO generally have the following characteristics: clean rice, no rocks, fluffier rice, fragrant, change color slowly when stored in the magic jar, not stale faster when heated until 3-4 days, savory taste, and contains antioxidants.

Certification of quality and test results of nutrition are also possessed advantages UD Padi, because there are not so many companies have organic rice. That advantage is the company's strategy to make acceptable HSO rice market, such as Holistic Hospital in Purwakarta, also readily accepted intermediaries, retailers or supermarket. Market segmentation is a factor to be considered for product strategy in marketing rice HSO conducted by UD Padi. There are three types of rice HSO for Diabetes (red pack), rice HSO for Family (blue pack), and rice HSO for Mother and Child (yellow pack). The existence of three types of rice HSO is an advantage possessed by UD Padi to seize market opportunities that have not been touched. This is because Diabetes HSO rice, sugar contains only $0.29 \%$, which is safe to consume for people with diabetes.

Discussion of strategy products cannot be separated from the life cycle of the product (Product Life Cycles), each product will have stages based on the passage of time. Although time is difficult to estimate, but each product will have stages, such as stages of introduction, growth, maturity and decline. At the time of research, marketing situation HSO rice conducted by UD Padi, especially in the area of Bekasi, is at the stage of growth. The determination is based on the consideration of the situation in sales volume continues to increase, the marketing area that has been reached, and the market segment dominated.

According Hardyastuti (2004), a strategy at this stage of growth is a competitive strategy that seeks company development in accordance with organizational goals. Strategy on Growth Phase, such as concentration strategies, market expansion strategy, and product development strategy.

\section{b. Price Strategy}

Pricing strategy is one of the marketing strategies that can affect the assessment of consumers into buying a product. In HSO rice marketing strategy, consumer prices or end user price is determined by the method of cost plus pricing, namely determining the selling price of goods is equal to the cost per unit plus the amount of the expected profit. U.D. Padi Headquarters determines the process of determining the price with the cost of shipment and the level of purchasing power. The most expensive HSO rice is HSO Rice Mother and Child, for Rp. 80.000,per pack. The Rice is more expensive than the others because it uses brown rice, which is more difficult to produce. The cheaper one is HSO Rice for people with Diabetes and HSO rice for family, each costing Rp. 60.000 ,- per pack. Factors that led to the high price because it is still imported from Japan. FEA of international clinical already tested, and a lot of manpower is needed in the sorting process, which is done manually, and the high cost of initial investment (land sterilization).

Pricing strategies undertaken to attract customers by giving a special price for the purchase of the package ( 3 types of rice HSO). Each purchase of the package, customers get special price in the form of a $10 \%$ discount. Another advantage for purchasing the package is free shipping for one area (the City and Region of Bekasi). In addition, it provides discounts for reseller's of $15 \%$ with a minimum purchase of 50 packs. 


\section{c. Distribution strategy}

The processes of distributing rice HSO along with two units below the distributor and single agent. Distributor in charge of distributing rice to each HSO Single Agent located in each region. Meanwhile, the single agent in charge of selling and marketing rice to consumers HSO either directly or through intermediaries. Ways in which, the U.D. Padi and Single agent for HSO distribute rice to the intermediary (retailer) is the first offering to the retailer. For large retailers such as supermarket, for example, Giant Super Market, a bidding process conducted by U.D. Padi Headquarters, while for small retailers such as pharmacies and outlets, the bidding process conducted by the Single agent.

The retailers who want to sell rice HSO, are required to pay Rp. $15,000,000$,- to U.D. Padi as a deposit to initial the purchase and have signed a contract of cooperation. With the fee, the retailer will have 200 packs of rice HSO, marketing tools (1 ream of brochures, business cards 1 box and 1 piece banners), sales training (training), and a gain of $25 \%$ of the purchase price of the final consumer (end user). U.D. Padi makes it easy for the retailer who has cash payment due. Method of payment is the retailer pays $50 \%$ (half) of the purchase price and the other half paid at certain time.

For the Bekasi area, U.D. Padi has been marketed to consumers either directly or through intermediaries (retailers). HSO rice marketing strategies undertaken by UD Padi are to reach consumers in the area of Bekasi, so consumers can easily obtain it.

\section{d. Promotion Strategy}

Promotional activities, for the moment, UD. Padi handed the Single agent for promotion in their respective areas. Media Promotions that can be used include brochures, advertisements in magazines, on radio and Internet advertising.

Several campaigns have been conducted by the Single agent Bekasi area "HSO Yasin" is Dakta Radio, Radar Bekasi Newspapers, brochures, and internet media (http://berasorganikhso.blogspot.com/). Obstacles faced with this promotion strategies rice HSO is only known at the regional level who are single agent or distributor areas that have been there alone. UD Padi Headquarters should also do promotion at the central level.

\section{External Environment Company}

\section{a. Macro External Environment}

Some components are included in the macro external environment among others:

1. Macroeconomics: Moving towards economic growth accompanied by raising incomes positive part of the community, is expected to boost purchasing power to buy quality rice as a daily consumption. Rice HSO as quality food commodities is expected to be an alternative to meet those needs.

2. Technology: Advances in technology, especially information technology, is expected to be positive for developing media and networking markets.

3. Natural Conditions: Changes in global environmental conditions have impact on the change of seasons, should be a concern for parties or corporate business activities 
depend on nature (agriculture), to determine the exact time of planting, pests and natural disasters are needed to be taken to ensure continuity of production. It should be anticipated with further intensify the cultivation process.

4. Demographic: The area of Bekasi, capital buffer zones, densely populated settlements. These conditions require rice to meet the needs of people everyday. Based on data from the Central Bureau of Statistics (BPS), a Bekasi resident death per 2,027,469 in July 2008. When referring to the contribution rate of rice consumption of $104 \mathrm{~kg} /$ capita / year, the rice needs of $210856776 \mathrm{~kg} /$ year or $210,856.776$ tons I year. If, the number of organic rice requirement of $2.5 \%$ of the annual consumption, the need for organic rice in Bekasi of $5,271,419.4 \mathrm{~kg} / \mathrm{year}$ or $5,271,418.4$ tons / year.

5. Government: Government launched a program to support the development of organic farming in "Go Organic 2010" with the program's mission such as: "To improve the quality of life and the natural environment of Indonesia, by encouraging the development of organic agriculture". U.D. Padi as one of the companies that produce organic rice in large quantities, have an important role in realizing the program.

\section{b. Micro External Environment}

1. Customer (Customer): Organic rice consumers today are upper middle class and are limited in big cities only. That is because there are still many people who do not know the advantages of organic rice and organic rice prices are more expensive than regular rice.

2. Competitors: Growing organic rice producers increased competition in the capture of the organic rice market. Currently, in the area of Bekasi, precisely in the area of Perurnnas 3 , there is another distributor of organic rice, but not rice HSO, it is the company's organic rice Ganesha Organic (GO), organic rice from farmers, which has pandan fragrance.

3. Distribution Channels: Not only limited to the grocery store alone but outlets and restaurants that specialize in providing organic menu also began to emerge. This condition can be used for organic rice companies, including UD Padi, Single agent "Yasin HSO", to distribute its products to consumers.

4. Supplier: Currently using seeds that are still imported from Japan, which is considered that the seed has a better quality than the local seed. The seeds have the same level with the local varieties such as Raja Wangi and Menthik Wangi.

5. Community: Rice demand will continue to increase until increasing population. This condition needs continuation to rise, from time to time, both quantity and quality.

\section{SWOT Analysis}

SWOT analysis (strengths, weaknesess, opportuinities, and threats) analysis is a tool that can give you an idea of the strengths and weaknesses that are owned and opportunities and threats towards the company that becomes the object of research.

\section{a. Rice Marketing Strengths and Weaknesses of HSO}

Overview of the strengths and weaknesses of UD Padi arwe in the following table. Profile of Strengths and Weaknesses Table Rice Marketing HSO.

\begin{tabular}{|c|l|l|l|}
\hline No. & \multicolumn{1}{|c|}{$\begin{array}{c}\text { Marketing } \\
\text { Strategy }\end{array}$} & \multicolumn{1}{c|}{ Strength } & \multicolumn{1}{c|}{ Weakness } \\
\hline 1. & Product Strategy & $\begin{array}{l}\text { + Product Specialization } \\
+ \text { Distribution Strategy } \\
\text { + Clinically tested and nutrient Content }\end{array}$ & $\begin{array}{l}\text { - High Cost Production } \\
\text { - Supplier Dependable } \\
\text { - Prone to Natural disaster }\end{array}$ \\
\hline
\end{tabular}




\begin{tabular}{|c|l|l|l|}
\hline & & $\begin{array}{l}\text { + Seeds From Japan } \\
+ \text { International Instructor }\end{array}$ & - Product Strategy (package) \\
\hline 2. & Price Strategy & $\begin{array}{l}\text { + Equal sharing profit with the Retailer } \\
\text { + Sales increment } \\
+ \text { Discount is available }\end{array}$ & $\begin{array}{l}\text { - the price relatively expensive } \\
\text { - lower price from competitor }\end{array}$ \\
\hline 3. & $\begin{array}{l}\text { Distribution } \\
\text { Strategy }\end{array}$ & $\begin{array}{l}\text { + Easy payment system for retailer } \\
+ \text { Optional service directly to consumer } \\
\text { + result certified }\end{array}$ & $\begin{array}{l}\text { - Double Job Desc at marketing unit (single } \\
\text { agent) }\end{array}$ \\
\hline 4. & $\begin{array}{l}\text { Promotion } \\
\text { Strategy }\end{array}$ & $\begin{array}{l}\text { Using internet as media } \\
\text { + Delivery service is available }\end{array}$ & - Promotion has been done locally \\
\hline
\end{tabular}

Analysis of strengths and weaknesses was conducted on a component in the company's internal factors including marketing management, financial management, human resource management, and production management.

\section{b. Analysis of Opportunities and Threats.}

External conditions may be opportunities and threats for the company as shown in the following table.

Table of HSO Rice Marketing Opportunities and Threats

\begin{tabular}{|c|c|c|c|}
\hline No. & Eksternal Factors & Opportunities & Threats \\
\hline 1. & Economy & $\begin{array}{l}\text { + Increased income for communities } \\
+ \text { Buyer and seller data will be increased }\end{array}$ & $\begin{array}{l}\text { Stagnant market } \\
\text { Economy crisis }\end{array}$ \\
\hline 2. & Technology & + Development of Information Technology & \\
\hline 3. & Demographya & $\begin{array}{l}\text { + Bekasi region as a residential land } \\
+ \text { Healthy and back to nature lifestyle }\end{array}$ & $\begin{array}{l}\text { Communities are not familiar with } \\
\text { organic product }\end{array}$ \\
\hline 4. & Nature & $\begin{array}{l}\text { + Condition of productive land } \\
+ \text { Good quality of air and water supply }\end{array}$ & $\begin{array}{l}\text { Disaster } \\
\text { Pests and diseases attack on crops }\end{array}$ \\
\hline 5. & Government & $\begin{array}{l}\text { + There is support from Central } \\
\text { Government and the Regional Program } \\
+ \text { Government organization is widely open } \\
\text { as distribution channel }\end{array}$ & \\
\hline 6. & Competitor & & $\begin{array}{l}\text { Cheap competitor price } \\
\text { The existence of initiative products }\end{array}$ \\
\hline
\end{tabular}

External conditions include the company, the economy, technology, culture, society, and government.

\section{c. Result Analysis}

SWOT analysis of the rice marketing HSO can be seen from the picture of the strengths and weaknesses and the opportunities and threats, which have been described previously. Analytical results obtained from the calculation of the value of marketing elements of each component using the scale, share, weights, ratings, and scores. Regarding the calculation of the value of rice marketing HSO, SWOT analysis can be seen in the following table.

SWOT Analysis Table Calculation

\begin{tabular}{|c|c|c|c|c|c|c|}
\hline \multirow{2}{*}{ SWOT } & \multirow[t]{2}{*}{ Environtment Analysis } & \multicolumn{5}{|c|}{ Component } \\
\hline & & Scale & Share & Weight & Rating & Score \\
\hline \multicolumn{7}{|c|}{ A. (Internal Factor) } \\
\hline \multirow[t]{6}{*}{ (S) } & Product Strategy & 4 & 20 & 0.10 & 4 & 0.40 \\
\hline & Certification & 4 & 20 & 0.10 & 3 & 0.30 \\
\hline & Distribution Strategy & 4 & 20 & 0.10 & 4 & 0.40 \\
\hline & Discount Availability & 4 & 20 & 0.10 & 3 & 0.30 \\
\hline & Optional Service & 4 & 20 & 0.10 & 3 & 0.30 \\
\hline & Total & 20 & 100 & 0.50 & & 1.70 \\
\hline$(\mathrm{W})$ & Expensive & 4 & 40 & 0.20 & 3 & 0.60 \\
\hline
\end{tabular}




\begin{tabular}{|c|c|c|c|c|c|c|}
\hline & Single land source production & 3 & 30 & 0.15 & 3 & 0.45 \\
\hline & Package (size) & 3 & 3 & 0.15 & 3 & 0.45 \\
\hline & Total & 10 & 100 & 0.50 & 9 & 1.50 \\
\hline \multicolumn{7}{|c|}{ B. (Eksternal Factors) } \\
\hline \multirow[t]{5}{*}{ (0) } & Increased income for communities & 5 & 27.8 & 0.14 & 4 & 0.56 \\
\hline & Development of Information Technology & 4 & 22.2 & 0.11 & 3 & 0.33 \\
\hline & $\begin{array}{l}\text { Government organization is widely open as } \\
\text { distribution channel }\end{array}$ & 5 & 27.8 & 0.14 & 4 & 0.56 \\
\hline & Government support & 4 & 22.2 & 0.11 & 3 & 0.33 \\
\hline & Total & 18 & 100 & 0.50 & & 1.78 \\
\hline \multirow[t]{5}{*}{$(\mathrm{T})$} & Undevelop market & 3 & 23.1 & 0.12 & 3 & 0.35 \\
\hline & Lower price from competitor & 4 & 30.8 & 0.15 & 3 & 0.46 \\
\hline & Nature Disturbance & 3 & 23.1 & 0.12 & 3 & 0.35 \\
\hline & Initiative product & 3 & 23.1 & 0.12 & 3 & 0.35 \\
\hline & Total & 13 & 100 & 0.50 & 12 & 1.50 \\
\hline Annotati & $\begin{array}{l}2=\text { Less important } \\
3=\text { Important } \\
4=\text { very important } \\
5=\text { urgent }\end{array}$ & Rating: & \multicolumn{2}{|c|}{$\begin{array}{l}\text { 1=no impact } \\
2=\text { less impact } \\
3=\text { there is impact } \\
4=\text { high impact }\end{array}$} & & \\
\hline
\end{tabular}

Based on the table above, the calculation of a SWOT analysis is done by using the calculation of scale, share, weights, ratings, and scores. Scales obtained from the assessment using the criteria of importance to not important (with numbers 1-5), obtained from the comparison between the share value of the scale 'with the scale total is multiplied by 100 , the weight gained from the share divided by 2 and multiplied by $100 \%$, the rating obtained from assessment influence the level of components, with criteria ranging from powerful to have no effect (with numbers 1-4), while the scores obtained from the weight multiplied by the rating.

The results of SWOT analysis, shows that the magnitudes of the component strength rice marketing HSO, at 1.70 and Weaknesses component of 1.50. As for the calculation of unknown components of 1.78 and Opportunities threats components of 1.50 . From these values it can be seen the value of the difference between strength-weakness (SW) of 0.20 , and the difference in value between opportunities-threats (01) of 0.28 .

\section{1). HSO Rice Marketing Position}

Based on me above values, the strength of U.D. Padi is dominant (positive numbers) and is accompanied by ample opportunities dominant anyway. It illustrates that the position of the company is on Sat I, so the marketing strategy for the next period to be aggressive (aggressive strategy). HSO rice marketing positions can be seen in the following figure.

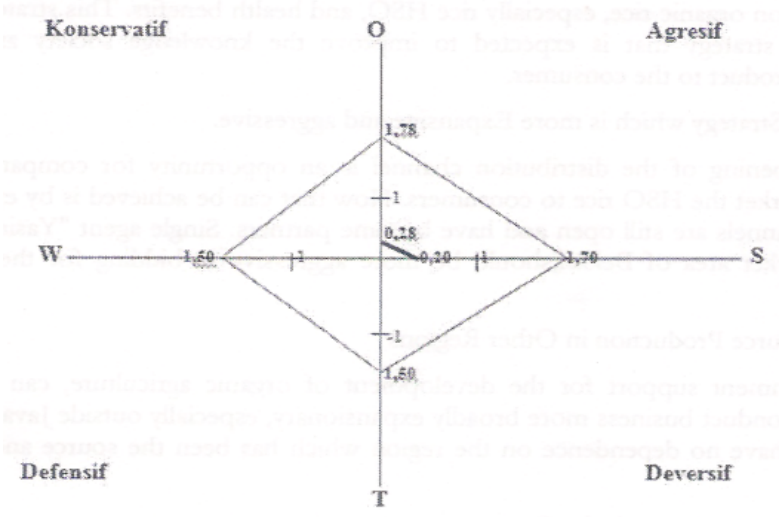


Based on the picture above, HSO rice marketing positions are in the Cell I (Strategy Aggressive). So HSO rice marketing strategy for the next period is the Aggressive Strategy. U.D. Padi, especially the Single agent "Yasin HSO", can utilize the company's internal strengths to achieve more market opportunities optimally.

\section{2). Matrix Strategy}

The strategy reflects the response organization (company) on the opportunities and threats from the external environment using a variety of strengths and weaknesses in order to gain a competitive advantage with its intended purpose (Hardyastusti, 2004). Response or strategy that can be done by U.D. Padi in addressing internal conditions (strengths and weaknesses) and external conditions (opportunities and threats) can be determined by observing table. Based on the matrix of five components of the strategy and the 4 components of rice marketing opportunities HSO owned by U.D. Padi, 6 pieces are produced as HSO rice marketing strategy for the next period:

\section{a) Retaining Qualified Production System}

HSO rice production system is done with pure organic farming systems; it needs to be maintained because they are made of rice HSO. It has a better quality than other organic rice. However, the thing to note is the considerable cost of production. Rice HSO is still using imported seeds and agricultural extension using foreign human resources and need to be considered because it is costly. In addition, the sources of production coming from the area of production should be taken into consideration, it is because they can be a threat if one time, facing interference source. In addition, this will affect the cost of shipping which is more expensive, especially for unit's Single agent outside the island of Java.

\section{b) Improving Enterprises Promotion}

For the foreseeable future, efforts should be improved by further promotion, and should not only be done by a single agency unit, but U.D. Padi (Headquarters) helped promote through greater promotion media such as national television.

Seeing other forces that are owned by the company, U.D. Padi, like having a certification and quality assurance, the product specialization, optimal HR, and a discounted price, should be used for promotional materials in order to attract more prospective customers.

\section{c) Utilizing Information Technology}

Information technology (internet) which is currently being developed in the community should be used by U.D. Padi. For further promotion HSO rice, it can be done by providing information and services to the public (potential customers). U.D. Padi, especially in the single agent unit, should provide a more instructive example by giving training, seminars, and consulting on organic rice, especially rice HSO, and health benefits. This strategy is part of a promotional strategy that is expected to improve the knowledge society as well as to introduce the product to the consumer.

\section{d) Distribution Strategy which is more Expansive and aggressive.}

The opening of the distribution channel is an opportunity for companies to more aggressively market the HSO rice to consumers. How that can be achieved is by expanding the distribution 
channels are still open and have become partners. Single agent "Yasin HSO" who knows the market area of Bekasi, should be more aggressive in bidding for the distribution channel.

\section{e) Adding Resource Production in Other Regions}

Government support for the development of organic agriculture can be used for companies to conduct business more broadly expansionary, especially outside Java. This will be very useful to have no dependence on the region, which has been the source and will reduce shipping costs.

\section{f) Increasing cooperation with the Government}

Government institutions, such as hospital pharmacies, for U.D. Padi is one of the units that could serve as the distributor (retailer) of rice to be acceptable to consumers HSO. Other form of cooperation that needs to be done is on the promotion of the movement back to natural (organic Go 2010), which has been announced by the government. This activity is expected to increase awareness to consume organic rice products, especially rice HSO.

\section{CONCLUSION}

1. Based on the results of the SWOT analysis, marketing strengili U.D. Padi dominant and accompanied by a dominant odd anyway, so the marketing strategy for the next period is an Aggressive Strategy. U.D. Padi, Single agent "Yasin HSO" internal company can harness the power to achieve a more optimal market opportunities.

2. Marketing strategy for U.D. Padi, Single agent "Yasin HSO" i.e: maintaining production systems, increased promotional efforts, utilizing technology for the promotion of information and services, distribution strategy is more aggressive and expansive, adding another source of production in the region, and enhance cooperation with the government.

Efforts have been made by U.D. Padi, especially the Single agent "Yasin HSO", the rice market HSO has done well, but to increase in the future, the promotion strategy should be done also by U.D. Padi by using a media campaign on national television. 


\section{References}

Adiningsih, Sri. (2005). Peranan Bahan Organik Tanah dalam meningkatkan kualitas dan produktivitas Lahan Pertanian. Jakarta: MAPORINA.

Agen Pemasaran Beras HSO Bekasi. (2006). Sistem Produksi Beras HSO. http://berasorganik.blogspot.com/12007/12/sistem-pertanian-beras-holistic-super.html

Andoko, Andoko. (2005). Budidaya Padi Secara Organik. Depok : P.T. Penebar Swadaya.

Damardjati, D. (2005). Kebijakan Operasional Pemerintah Dalam Pengembangan Pertanian Organik di Indonesia. Jakarta : MAPORINA.

Firdaus, Muhammad, Lukman M. Baga, dan Purdiyanti Pratiwi. (2008). Swasembada Beras dari Masa ke masa. Telaah Efektifitas Kebijakan dan Perumusan Strategi Nasional. Bogor: IPB Press.

Hardyastuti, Suhatmini. (2004), Manajemen Strategi. (Modul Mata). Program Studi Pascasarjana. Yogykarta: Manajemen Agribisnis UGM.

Ismail, EH. (2010). Sawah Puso Diganti Rugi. Republika, Selasa, 23 Februari, hlm: 14.

Kenedy, Jhon E. (2009). Era Bisnis Ramah Lingkungan. Strategi Marketing Comunication Masa Depan. Jakarta: P.T. Buana Ilmu Populer.

Kotler, Phillip dan Gary Amstrong. (2005). Dasar-Dasar Pemasaran. Jilid 1. Jakarta: Prenhall Indo.

Murdiyarso, Daniel. (2005). CDM: Mekanisme Pembangunan Bersih. Jakarta: Buku Kompas.

Nazir, M. (2003). Metode Penelitian. Jakarta: P.T.Ghalia Indonesia.

Portalhr. (2008). "Selain Bikin Sehat, Beras Organik juga Ciptakan Peluang Bisnis" http://www.portalhr.com/majalah/edisisebelum nya/bisnis/1id977.html

Rangkuti, Freddy. (2005). Analisis SWOT Teknik Membedab Kasus Bisnis. Jakarta: PT. Gramedia Pustaka Utama.

Sumarni, Murti dan Jhon Soeprihanto. (2008). Pengantar Bisnis (Dasar-Dasar Ekonomi Perusahaan). Yogyakarta : Liberty.

SUSENAS. (2008). "Sosialisasi Situasi Konsumsi Pangan". http://bkp.deptan.go.id/index2.php?option=com_content\&do_pdf=|\&id73

Untung Jaya. (2009). "Usahakan Swasembada Beras Berkelanjutan". Majalah AGRINA. Volume 4. No : 93. Halaman 9.

Warung Organik. (2008). "Riset Medis Beras Holistic Super Organic". http://www.warungorganik.coml?riset-med is-beras-diabetes-holistic-super organik, 30. 
Marketing Analysis Strategy Organic Rice At Ud. Padi Marketing Region Bekasi With Single Agent (Yasin Holistic Super Organic)

Website Pemerintah Kabupaten Bekasi. (2008). Rencana Pembangunan-Program Lima Tahun. http://www.bekasikab.go.id/www/html 3tno.php\# 